\title{
Language and Ethnicity among Coloured Students in Cape Town ${ }^{1}$
}

\author{
Mônica Savedra ${ }^{a}$ \\ Peter Rosenberg ${ }^{b}$ \\ Anderson Lucas Macedoc
}

${ }^{1} \mathrm{O}$ presente trabalho foi realizado com o apoio da Coordenação de Aperfeiçoamento de Pessoal de Nível Superior - Brasil (CAPES). Código de financiamento 001.

\begin{abstract}
This paper raises the issue of the relationship between language and identity. This subject has been present not only in Sociolinguistics, but also in other social sciences in recent decades. The focus here is to describe and present the relationship between the Afrikaans language spoken by university students who are members of the Coloured population and the ethnolinguistic identity perceived by these speakers. The locus is the multicultural and multilingual Cape Town, located in the South African Western Cape province, where European colonization began. To achieve the objective of this article, we briefly present the language in question: its emergence, its history and by whom it is currently spoken. In addition, since we are dealing with a somehow hybrid ethnicity ("coloured"), we also use anthropological theoretical approaches to understand what is perceived as "ethnicity". With regard to data collection, we use qualitative content analysis. Internet interviews were conducted through the platform known as Zoom. Eight students were interviewed and answered a set of questions about the social role of the varieties
\end{abstract}

Recebido em: 28/09/2020

Aceito em: 11/11/2020

a Universidade Federal Fluminense - UFF; Conselho Nacional de Pesquisa (CNPq); Fundação

Carlos Chagas Filho de amparo à pesquisa do estado do Rio de Janeiro (FAPERJ), Niterói, RJ, Brasil.

E-mail: msavedra@id.uff.br

b Europa-Universität Viadrina (Frankfurt-Oder); DAAD - Deutsche Akademische Austauschdienst, Frankfurt (Oder), Alemanha. E-mail: rosenberg@europa-uni.de

c Universidade Federal Fluminense; Conselho Nacional de Pesquisa (CNPq), Niterói, RJ, Brasil.

E-mail: andersonlucasm@gmail.com

\section{How to cite:}

Savedra, M.; Rosenberg, P.; Macedo, A. L. Language and Ethnicity among Coloured Students in Cape Town. Gragoatá, Niterói, v.26, n.54, p. 380-404, 2021. <https://doi.org/10.22409/gragoata.v26i54.46355> 
of Afrikaans in Cape Town, attitudes concerning language status and linguistic representation of identity and belonging, in which language(s) they feel best represented, among other issues. The results obtained from the interviews brought a broad understanding of the linguistic practices of these Coloured speakers.

Keywords: Identity. Belonging. Ethnicity. Afrikaans.

\section{Introduction}

In the last four decades, the study of social and linguistic identity has gained a lot of attention in social sciences, and particularly in Sociolinguistics. The issue of identity is currently recognized as something that is mutable, non-exclusive, and that is being constructed by the individual and by people who share similar values. Omoniyi and White (2006) show that Sociolinguistics has been concerned not only with explaining linguistic and social phenomena, but with the practices to impact social interaction. Emphasizing the construction of identities, sociolinguistic studies have to deal with the multiple and fluent ways of negotiating belonging in which individuals construct their social positions through language(s).

A special perception of identity is ethnicity, which is connected to the "social organization of culture difference" (BARTH, 1969), an order based on (ethnic) origin: under certain conditions, people perceive ethnic belonging as most characterizing and best categorizing the social position of people sharing common features. One important feature that serves to construct ethnic groups is language. This paper deals with the question of identity and language in a very specific environment: the Coloured community located in the

${ }^{2}$ Cape Town is the second most populous city in South Africa. It is located in the province of Western Cape. multi-multilingual Cape Town ${ }^{2}$ of South Africa. It focuses on exploring the relationship between the Afrikaans language and a perceived ethnic identity through the linguistic practices revealed by Coloured speakers in a plurilingual context. Basically, this research deals with the social positioning of 
Coloured speakers with respect to two varieties of Afrikaans language, called by the speakers: "Coloured Afrikaans" and "White Afrikaans". Both varieties exist in the same plurilingual context.

'Coloured Afrikaans' was described by our interviewees as informal, as "slang", and as a mix with English. For 'White Afrikaans', on the other hand, informants used expressions like traditional, proper, and authentic.

The subject of this paper will be dealt with in the following way: The first part briefly presents the Afrikaans language in South Africa and its importance for the society in the past and the present. Secondly, we will discuss the social position of the Coloured population and its linguistic variety ('Coloured Afrikaans'). In the third section, the theoretical approach, based on anthropological and ethnological findings, will be presented. The fourth part describes the methods of data collection we used in this work. In detail, we present and discuss the results we obtained from the interview data collected. The contribution will be finished by conclusions related to the issue of language and ethnicity among Coloured students in Cape Town.

\section{Coloured people in Cape Town: language contact}

"Diverse" is certainly a proper adjective to describe South Africa. In linguistic terms, this multilingual and multicultural country is a place for many Bantu languages like Zulu (or isiZulu) and Xhosa (or isiXhosa) as well as Germanic languages like Afrikaans and English. In Mesthrie's (2004) words, "South Africa has been the meeting ground of speakers of languages belonging to several major families, the chief ones being Khoesan, Niger-Congo, Indo-European and Sign Language"

${ }^{3}$ EBERHARD; SIMONS; FENNIG (eds.) (2020), online as: <http://www. ethnologue.com>.

${ }^{4}$ Capitalization will be used when referring to communities perceived as ethnic. (MESTHRIE, 2004, p. 11).

Afrikaans - the subject of this paper - is the language of around 6,860,000 people in South Africa as L1. More than half of these users are not white as claim Webb and Kriel (2000), and 10,300,000 as L2. ${ }^{3}$ It is important to make clear that Afrikaans is basically spoken by the White community (the direct descendants of the European settlers) and the Coloured community ${ }^{4}$. This language is also spoken in Namibia and in parts of Zimbabwe. Most of its lexicon is Dutch-based, although 
it is possible to find words from Khoisan languages and other European languages. Today, Afrikaans is the third most spoken language (around 13.5\% of the population) in South Africa after Zulu and Xhosa, respectively.

Afrikaans played an important role in the former South African political system, apartheid. Many may relate this language directly to apartheid, which entails a negative attitude towards the language as representative of "racial" discrimination and White colonialism.

\begin{abstract}
The social meaning of Afrikaans is very divergent. On the one hand it is regarded as a fundamental symbol of sociocultural identity by many of its white speakers, who profess to "love" it and are prepared to sacrifice (materially) for its continued maintenance; on the other hand, its direct association with the policy and practice of apartheid has led to its extreme stigmatization, particularly among black South Africans. In between these extreme positions there are, of course, varying degrees of social meaning, with Afrikaans considered by some mainly as a means of communication, but functioning for others as an instrument of solidarity and/or separation. (WEBB; KRIEL, 2000, p. 21)
\end{abstract}

In the "New South Africa", where 11 languages are recognized as official, English has taken much of Afrikaans' privileges and power, especially in public sphere, state administration, and politics. This can be explained by global and local economic issues, and also by social factors; first of all, by an attitude that associates English with an anti-colonialist disposition of the new post-apartheid South Africa. "English in South Africa enjoys enormous status for black people, marking the speaker as educated, affluent, serious or authoritative" (SLABBERT; FINLAYSON, 2000, p. 128). While Afrikaans serves as a symbol of apartheid, elements of English (which has also been a language of colonial power) within language mixing sequences are "typical of urban speech" (SLABBERT; FINLAYSON, 2000, p. 128). The number of Afrikaans schools has decreased since 1994, the year of the end of apartheid, because the educational system felt the pressure to use English instead. In spite of all marginalization, disempowerment and its controversial historical background during the last century, Afrikaans remains a language with a high degree of vitality; 
it is used on public television, in music production, in the education system (schools and universities). Webb (2010) calls our attention to what he names a "third Afrikaans language movement" that is currently happening. Such movement started in 2003 and consists of an initiative of a number of Afrikaans institutions cooperating to promote their language and culture. As an example, there is a National Language Conference on Afrikaans; a few other events for language planning and promotion of the language in official functions and even a meeting to discuss Afrikaans as a language of science. Some of the initiators also proposed the union of all the communities who use Afrikaans so it could gain strength.

Since this article investigates the relationship between language and identity within the geographical limits of Cape Town - all the students interviewed study in this city - it is important to understand the linguistic contact that exists in this city for a deeper understanding of the data that will be presented here: The three most spoken languages in Cape Town are Afrikaans, Xhosa and English. However, many other languages (and varieties of Afrikaans and Xhosa) can be found in the Cape, since a large number of migrants and immigrants live in the city. Deumert; Inder and Maitra (2005, p. 309) argue that "Cape Town... is a historically multilingual city with two dominant languages: English and Afrikaans" (DEUMERT; INDER; MAITRA, 2005, p. 309), however due to the great migrant movement of people from Eastern Cape the number of Xhosa speakers has risen and has overtaken English as the second most spoken language.

Deumert; Inder and Maitra (2005, p. 309) explain that the Xhosa language is still marginalized in various ways:

However, this overall demographic growth in language distribution and the recognition of Xhosa as one of the three official languages of the Western Cape (...) has had little effect on the role Xhosa plays in the formal urban economy and public life: the majority of Xhosa speakers are socioeconomically marginalized and live in the urban slums which are located mainly in the eastern part of the city. (DEUMERT; INDER; MAITRA, 2005, p. 309)

According to the authors, Afrikaans still has a relevant position in the public service; however, English is becoming 
more frequent in this domain. In Cape Town, English has been employed as "a bridging language in interethnic communication" (DEUMERT; INDER and MAITRA, 2005, p. $310)$, and it helps citizens to participate in political and social life. "English provides the linguistic means for socio-economic advancement and facilitates access to government services" (DEUMERT; INDER; MAITRA, 2005, p. 310).

Figure 1 illustrates the linguistic situation of Cape Town presented above. According to the 2011 census, Afrikaans is the most widely spoken language in Cape Town; the second most spoken language is Xhosa and then comes English:

\section{Languages}

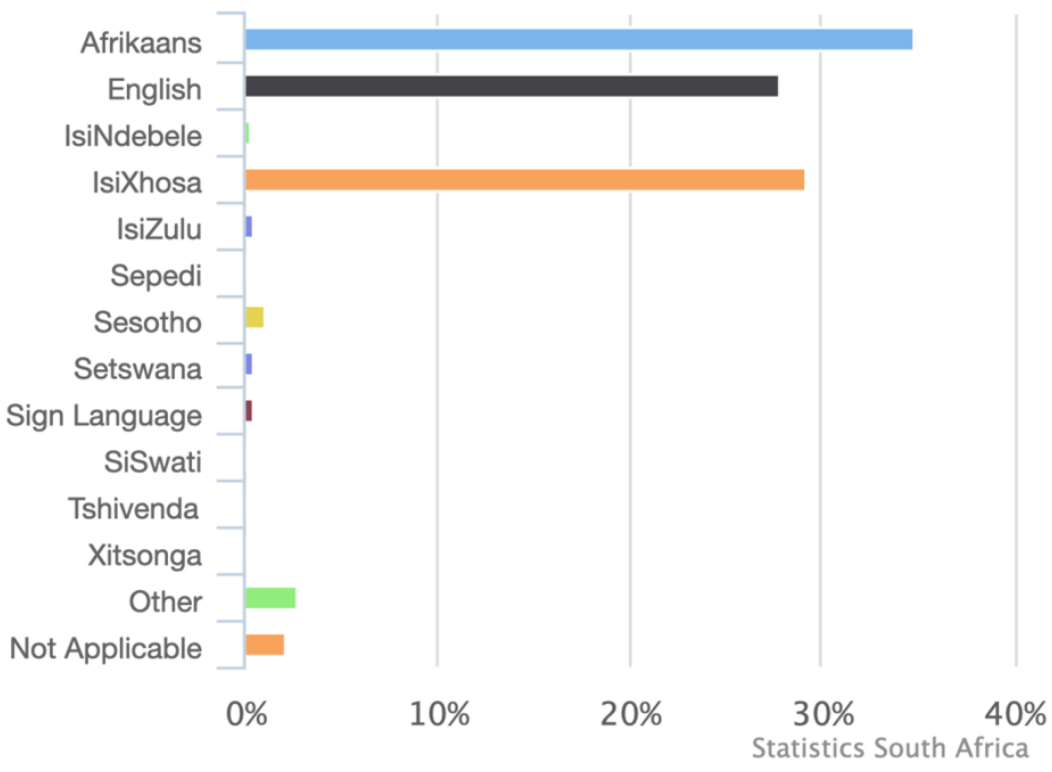

${ }^{5}$ Source: <http://www statssa.gov.za/?page_ id=993\&id=cityof-cape-townmunicipality>, 30.09.2020 (chart accessible under "people" down on this website).

Figure 1 - Percentage of people in Cape Town speaking these languages as first language ${ }^{5}$

\section{Historical origins of the Coloured community}

Our central attention in this paper is on the Afrikaans spoken by the Coloured community in the Western Cape. The Coloured people, roughly speaking, are a multi-ethnic population in South Africa, which has been called and still calls for an "ethnic" status. Their miscegenation started in 1652 when the Dutch turned the region today known as Cape Town into a provisioning station and protective garrison. 
${ }^{6}$ Khoisan are the non-Bantu indigenous people of Southern Africa. The Khoisan languages are, among other features,

known by the click consonants.

${ }^{7}$ Western Cape is the province where the Dutch settlement began. Cape Town is the biggest city in the province.
Last century, during the apartheid years, the term "coloured" was used to indicate people who were not "white" or "black", even though there were a considerable number of differences (physical features) among them. Hence, the term "coloured" while firmly established and traditionally used - traces back to a "racial" category invented by colonial power relations. It defines the population "in-between" the rulers and the subordinated ones, and it allowed for social aspirations of (limited) ethnic "advancement" (depending on concord with whiteness criteria).

In the $17^{\text {th }}$ century, the Dutch presence in the Cape changed completely the life the indigenous hunter-gatherers used to have and the settlement promoted contact among several languages, mostly Dutch and Khoisan ${ }^{6}$ languages. The Dutch also brought to the Cape a large number of enslaved people from other areas of Africa and also Asia. Hence, there were several languages spoken in the colony of that period contributing to the formation of Afrikaans.

Nowadays, the Coloureds are a numerous population in Western Cape $^{7}$ according to the Census 2011 amounting to $4,615,401$ people in this province - around $45 \%$ of the total population. The Whites make up $4,586,838$, Blacks make up 1,912, 547 and the Asians make up 60,761. In the map below, we can notice that most of the Coloured people are concentrated on the western side.

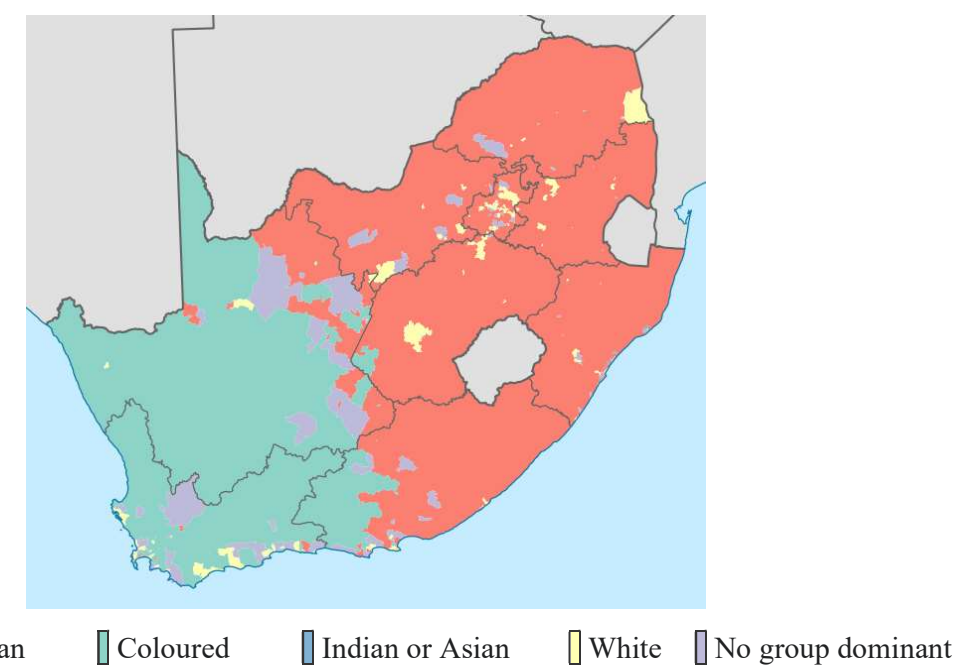

Figure 2 - South Africa 2011: Distribution of population ${ }^{8}$

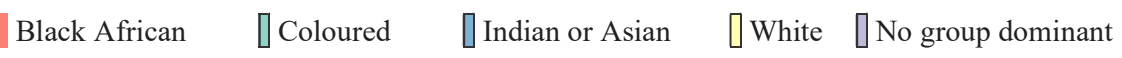

${ }^{8}$ Source based on the Statistics South Africa's Census 2011 population data, processed by Htonl: https://commons. wikimedia.org/ wiki/File:South Africa_2011_ dominant_population group_map.svg, 30.09.2020. 
${ }^{9}$ According to the students interviewed, 'proper Afrikaans' is the 'correct' and 'more formal' way of speaking it and it is spoken by the Whites.
Contemporary Western Cape, especially the Cape Town area, is a place of many languages in contact, which reflects the social and linguistic diversity. Dowling et al. (2020) carried out a study on language contact in Cape Town. The authors mentioned that the Coloured people often speak a blend of Afrikaans and English. As we will show in more detail in section 4, almost all of our interviewees referred to it as "slang" or "an informal Afrikaans" in contrast to the "proper Afrikaans. ${ }^{9}$ The authors also pointed out the very common practice of code- switching among the Coloureds. In the Chapel Street Neighbourhood, for instance, if a person doesn't mix languages, he/she will probably cause a strange feeling in others (DOWLING; MCCORMICK; DYERS, 2020, p.134). In working-class communities in Cape Town, Coloureds use local non-standard Afrikaans and English, often in code-mixing.

Language mixing, however, is often seen as an unwanted feature of linguistic incompetence, of weak ethnic belonging, hence, of social as well as linguistic "contamination". Since language ideologies tend to exclude heterogeneous practices and to prefer homogeneous social belonging symbolized by homogeneous means of expression, we could ask what the attraction of ethnicity might be.

\section{The attraction of ethnicity}

In modern anthropology, ethnicity is not seen to be "given" by the essence of origin, language or culture, but constructed by choice and evaluation of social relations. This is the famous contribution made by Fredrik Barth 1969, the forefather of ethnological constructivism who stated that the most important process is in ethnic boundary marking: "the critical focus of investigation from this point of view becomes the ethnic boundary that defines the group, not the cultural stuff that it encloses" (BARTH, 1969, p. 16).

Brubaker (2002) warns against the tradition of "groupism", which takes (ethnic) groups for "things in the world" instead of appraising a shared and imagined "groupness". Groups are "what we want to explain, not what we want to explain things with" (BRUBAKER, 2002, p. 165).

The truth of this advice has long been known in ethnic conflicts, when ethnic movements were mobilized by ethnic 
leaders for the sake of their own power. Soon, an ethnic frame was constructed on all sides of the conflicts and belonging to ethnic groups was driven into irreconcilability: either this ethnic group - or that one. And a supraethnic sense of belonging (to one country or one nation) was vanishing.

In postmodern terminology, Joanna Pfaff-Czarnecka (2011) suggests using the concept of "belonging" not "identity" with the aim to assess the heterogeneous and multilingual group memberships and the degree of incorporation into different groups. The sense of belonging depends on commonalities of the group members, of the mutuality and reciprocity of acknowledgment, and of the (material or immaterial) attachment to common issues. Focussing on the dynamics of belonging - of social practices and "acts of identity" (LE PAGE; TABOURET-KELLER, 1985) - is certainly an advantage of this constructivist approach. There is no need, however, to abandon the notion of "identity": After all, the multiple facets of group belongings do not invalidate the individual's pursuit of identity. On the contrary: the more facets of multiple belonging the individual perceives, the more important is the construction of an overall identity - in order to feel oneself as one person over time, space, and social roles.

The notion of construction has become widely accepted in social sciences and in interactional sociolinguistics. Moreover, sometimes, in postcolonial studies, construction appears as a deus ex machina, a kind of passe-partout explanation, which shifts the field of interpretation from interaction to mental states. But since we have to explain the emergence of boundaries (of social, ethnic or national groups), since some ethnic groups are accepted and others are neglected, we still have to answer some questions: What are the resources of ethnicity? And what is the impact of language in boundary marking?

Boundaries may be differentiated according to three

${ }^{10} \mathrm{Cf}$. SCHIFFAUER et al. (2018). criteria: durability (stability), permeability (allowing crossing or not), and liminality (abrupt or smooth transition)..$^{10}$ What causes the construction of a disruptive boundary or its character as a blurred one?

Fredrik Barth (1994) conceded 25 years after his programmatic proposition: 
I overstated this point (of cultural differences of primary significance for ethnicity used to mark the boundary) in the formulation that people's choice of diacritica appeared arbitrary. [...] These reifications have consequences, but not the consequences of simply creating the communities and the properties that are imagined, by the mere act of imagining. [...] If ethnicity is the social organization of culture difference, we need to transcend habitual conceptions of this thing 'culture'. What we subsume under the concept of culture no doubt has empirical properties which will be relevant to an understanding of ethnicity [...] Though highly contextual and contingent, the selection of such diacritica is far less haphazard than I may have indicated in 1969. (BARTH, 1994, p. 12-15)

Construction, hence, is not arbitrary, not just an imagination, but as a social organization of cultural difference, it consists in structuring experience along with central cultural values.

The German sociologist Hartmut Esser asks why ethnicity is still so attractive. In his answer, he focuses on the rationality, not the irrationality of ethnic actors even if people in ethnic riots do crazy things. According to Esser, ethnic groups are defined by three criteria: differentiation, ascription, and specific capital.

Differentiation: Ethnic groups are identified and identify themselves by certain differences from out-groups. Among other issues, origin is a powerful criterion of these "imagined communities" (ANDERSON, 1988). Origin has the unique attractiveness that you are born into an ethnic community and you can't acquire origin. In a way, this is a resource of uniqueness (and a promise of eternity).

Tradition is a symbol of that origin. Shared knowledge and values are connected to tradition which leads to a sense of belonging. A strong boundary marker - among others (like territory, religion, historical memory) - is language as our primary means of social behaviour.

Ascription: Ethnicity is shared by a subjective sense of belonging - and this is true for the in-group itself as well as for the out-group. Even an oppressed minority might be considered by in-group and out-group an ethnic entity. The ascription of certain "characteristics" of the ethnic community (by the in-group as well as by the out-group) is, in fact, what 
Barth (1969) described as "boundary marking": The ascription of perceived features to the own "group" as a contrasting procedure to construct an identity by focusing on difference from others, a procedure which has been called "othering".

Specific capital: Ethnic communities may possess specific capital more than generalized capital. Specific capital is knowledge, skills, behavior, traditions, ethics, property, organizations: a set of goods that are only usable for and within the ethnic group while generalized capital is useful for everybody (like money, education, land).

The powerfulness and intransigence of ethnic conflicts are closely tied to the strategy of establishing specific ethnic capital as the decisive criterion of power: In an ethnic state, the specific capital of just one group is ruling. That means only members of this group have access to power, only the values of this group are accepted, only the language of this group is admitted. And remember: You cannot acquire ethnic origin. Therefore, establishing ethnic capital as the prerequisite of access is the admission ticket to everything while any other ethnic group can be excluded from power. Apparently, this has been the case in apartheid.

This strategy is rational, not irrational, if an ethnic frame is perceived as the only useful explanation of the state of a society.

Nevertheless, under which condition prevails an ethnic frame? And why do even marginalized ethnic groups obey an ethnic frame, even if they do not participate in power, like the suppressed ethnic groups in South Africa?

Obviously, a frame is chosen by people as the most convincing interpretation to understand what is going on. And sometimes a frame changes if it loses its convincing force.

Apparently, in times of change, people get the conviction that the old interpretation of legitimacy was wrong: In apartheid times, people have been told, you may live safe (while not well) if you are a law-abiding citizen, and a hardworking member of society. Long ago, people began to doubt this attitude, and social inequality was interpreted as ethnic or "racial". The old legitimacy was felt to be false - a new one spread which said: you have to be white to get access to power and welfare. If you are not white, you will always be inferior. Why should it be of higher value if you have a whiter (or a paler) 
skin? Obviously, the new frame, the ethnic or "racial" frame, was accepted as a better explanation of the world which was perceived as a world of injustice caused by ethnic or "racial" stratification.

Nowadays, this frame, again, is challenged. The options are to search, either, for a better explanation of what is happening in post-apartheid South Africa. Or to demand an ethnic status in a still ethnic or "racial" frame, for example as Coloured.

Esser, as an advocate of the rational choice $\left(\mathrm{rc}^{+}\right)$approach, emphasizes utility and attitudes as decisive in framing.

In other words, a new framing will be chosen if benefits and a fitting interpretation of the situation suggest this frame: As we have seen, the benefits of the mobilizing resource of a specific ethnic capital are promising. And an ethnic interpretation is still at hand since the ethnic or "racial" fundament of the South African society is common sense. As we see: What is most persuasive in maintaining or changing a given frame is attitudes. Even a marginalized ethnic group may conquer with the powerful ethnic group and struggle for rights on the common ground of a generally accepted (ethnic or "racial") frame as long as ethnicity (or what is perceived as "race") is best explaining what society is based on. And there is still some evidence that ethnic or "racial" criteria do help to comprehend power relations, everyday experience of living, of earning money, of acquiring status, of achieving educational success, or of winding up in prison.

\section{The Interview Study: Language and Sense of Belonging of Coloured Students in Cape Town}

The investigation followed the methodology of qualitative research, used in ethnolinguistics, which aimed to understand the sociolinguistic behaviour of Coloured university students in Cape Town. The procedure we chose was the method of qualitative interviews, which were done via internet through the platform known as Zoom. This way we could collect data on the social positioning of 'Coloured speakers of Afrikaans' in Cape Town. By semi-structured interviews, we sought to identify the linguistic attitudes, the linguistic representation and the feeling of belonging of the interviewees regarding their 
social positioning and their use of language(s). The interviews were conducted in English.

Besides the interviews, we carried out a sociolinguistic survey from which we could select the eight informants. In total 59 people responded to the questionnaire which was sent by Google Forms.

The eight selected informants for the study had to follow these criteria:

a. Be a university student at a Cape Town educational institution

b. Be born in the period known as post-apartheid

c. Identify themselves as Coloureds and be speakers of Afrikaans

The reason for choosing university students was because we believe that university students have proficiency in English that would allow them to participate in the interview confidently. The questions used in the interviews required people who could express themselves clearly in English. We decided to analyze the attitudes of the informants born only in "New South Africa" (after the end of the apartheid). And, finally, we chose to interview speakers who identify themselves as Coloureds and be speakers of "Coloured-Afrikaans", as this is the central focus of this study. As presented, eight university students were selected for this research, aged 1825 years old. They are bilinguals (English and Afrikaans) and some expressed the interest in learning Xhosa language. To find the informants within the delimited profile, we searched through internet pages of the main universities of Cape Town as well as in social media (Facebook and Instagram). Some students responded to our contact very positively and agreed in participating in the interviews.

Some of the students used a computer to be interviewed and others used a cell phone. The chosen platform allowed online conversations with considerable quality, in addition to providing the recording of the collection.

The interviews conducted in this research are classified as semi-structured, as we used a previously prepared interviewguideline, with the following questions: 
a. How would you describe the position of coloured people in South Africa in genexral?

b. Does it apply to you or only to average coloured people?

c. Have you ever felt any (positive or negative) appraisal to be an Afrikaans speaker, particularly as a coloured speaker, by others?

d. Do you socialize with people from other languages the same as with Afrikaans speaking people?

e. Which Afrikaans variety do you believe you adopt?

f. Do you consider/see (agree) Afrikaans as one of the national languages in South Africa?

g. How is your Afrikaans variety labelled by your own community and the other communities, do you think?

h. Do you think the white Afrikaners have a positive, negative or neutral attitude towards your Afrikaans variety?

i. Do you think the Xhosa people in CT have a positive, negative or neutral attitude towards your Afrikaans variety?

j. Would you say that you love your Afrikaans variety?

k. In your opinion, do the young coloured people have something special in the way they express their culture/language in society?

The code list below extracted by Qualitative Content Analysis (cf. MAYRING, 2014) shows briefly the main subjects present in the questions and answers used in the interviews:

- How the Coloured community is seen by the Coloureds themselves

- How Coloureds perceive the attitude of other ethnic groups towards them as Afrikaans speakers

- How they perceive the domains and the social prestige of Afrikaans in the South African society and how they think other ethnic groups perceive it.

- Relations of belonging with their community related to their language variety.

As the interviews were intended to be brief (in order to encourage student participation), it was believed that the 11 questions were enough to promote a conversation about the 
relation between the relation of the Afrikaans language and their sense of belonging and to raise the desired information. The interviews lasted an average of 20 minutes. Respondents were encouraged to speak as much as they like about the proposed topics. In addition to the prepared questions (the deductive part of questioning), it was also possible to infer any questions and clarifications (the inductive part), following the natural flow of the conversation.

The analysis of the interviews was methodologically based on the Qualitative Content Analysis (MAYRING, 2014), and theoretically on the framework described in the previous section, where we approached the topic of ethnicity.

Below, we present the analysis of the research carried out, which was based on the identification of the most treated and most important subjects, such as: the linguistic representation Coloured Afrikaans (opposed to of the White Afrikaans); the feeling of belonging of the Coloured with their linguistic community.

\section{Attitudes of Coloured Afrikaans speakers towards languages and language varieties}

Attitudes towards languages and language mixing are different: some residents find language mixing completely superficial or negative, but others have a less judgmental opinion and see it as a normal way of communication that should not be changed. Coloured people from rural areas often do not have as much exposure to English as the ones in the city and, therefore, their usage of Afrikaans does not present a lot of mixing and switching.

Some Coloured speakers who live in the Afrikaans speaking area in the interior of the country with contact to the white farmers have learned a more homogeneous standard variety of Afrikaans, which gives them access to the white middle class. Also, the rural Coloureds perceive much less presence of 'slang' in their linguistic variety. One of our interviewees who went to Cape Town to study at a university stated:

(1) Initially I thought there was just one Afrikaans, when I came to university I realized it wasn't the case because people of Cape Town speak a different Afrikaans from people to 
(a certain town), White people speak a different Afrikaans from coloured people so [...] I feel like, how do I call this? I feel like my type of Afrikaans is more like... it doesn't have much slang in it like people from Cape Town" (Interviewee 1)

In Slabbert and Finlayson (2000, p. 128), the authors mentioned that English sequences "mark the urban/township individual as 'modern', 'Westernized', and 'educated'".

On the other hand, our own results offer insights into a debate on "purity" of "proper Afrikaans", which would be contaminated by English elements thus marked as "slang", while the Afrikaans language of the white farmers represents a somehow more educated use of the language. Trying to define both formal (White-Afrikaans) and informal (Coloured) Afrikaans, one of the students explained:

(2) When you listen to the cape Town Afrikaans is a way different from our Afrikaans in the North you know is a much purer Afrikaans here they mix it with English and different other words that they add to the Afrikaans (Interviewee 8)

Trying to define both formal (White-Afrikaans) and informal (Coloured) Afrikaans, one of the students explained:

(3) Proper Afrikaans is when people can speak it really well; it's called suiwer Afrikaans [...] proper Afrikaans with no slang involved [...] and the kombuis Afrikaans which predominantly all Coloureds speak, mostly the older generation of coloureds speaks Afrikaans with slangs, kombuis Afrikaans. (Interviewee 2)

Notice that he used the word suiwer (which means "pure" in English) and the expression kombuis to refer to the coloured variety of Afrikaans. Kombuis actually means "kitchen", but when it is used with the name of languages it means a "simpler" or "less sophisticated" way of using it. All respondents share the same opinion about the informality that this variety expresses, however, this is not seen as an inferior or "broken" version of Afrikaans. The respondents were actually critical of the way their linguistic variety has been seen:

(4) when some Coloured people are exposed to White people, we try to talk like they talk, it almost feels like we are uplifting our speech or way of speaking to get on their level of 
11 Taken from a "programmatic" YouTube video "Rise in Power to Kaaps" from 2019: https:// www.youtube.com/wa tch? $\mathrm{v}=\mathrm{yNg} 4 \mathrm{R} 2 \mathrm{G} 5 \mathrm{QzY}$ \&list=PLCxKtdoNvHX7FkPtLphWBcCPqqIop26B
${ }^{12}$ Boere means 'farmer'. The term refers to the White community in South Africa that descended from the Dutch colonizers. communication, if you know what I mean [...] you naturally feel the tension, I feel the tension when I am confronted by a White person when I am in the company of a White person you feel the tension of I'm a bit lower than you. (Interviewee 2)

Lately, a new pride of "Afrikaaps", the spoken language of poor Coloureds in Cape Town, has emerged taking the variety as a representation of a cultural identity, thus countering a linguistic ideology where speakers have been ashamed of the language: "Afrikaaps is not slang, Afrikaaps is not broken. Afrikaaps is not a lesser version of anything spoken. It's rich in history, it's diverse in structure. It's the linguistic identity of an entire culture. It apologizes to no one".11

Regarding the cultural and linguistic pride of Coloured people two interviewees stated:

(5) We enjoyed the fact that we have that kind of Afrikaans. (Interviewee 3)

(6) I think it's unique and speaks a little bit about where you come from and it's almost like you belong to a certain group (Interviewee 4)

Dowling; McCormick; Dyers (2020) also comment on heterogeneous people's attitudes towards standard Afrikaans. Some of their interviewees reject the Afrikaans spoken by the white speakers (or the 'proper Afrikaans', as our interviewees name it) because it reminds them of the years of apartheid rigid policies. Some others are capable of separating their dislike for the prior government and the Afrikaans language. In our own results, one of the interviewed students expressed her ideas on the White Afrikaans speakers' attitude towards her:

(7) from my personal experience, from my point of view, I think Boer ${ }^{12}$ White would basically look down on you because of your, our kind of Afrikaans. (Interviewee 3)

(8) During my high school years at a predominately White race school with Afrikaans people there is a natural feeling [...] you can feel there's a sense of hierarchy, you know, and White people would always joke around, Afrikaans White people would joke around, use the Coloured or try to speak in a Coloured accent you know in that flat kind of dialect whatever as a joke whatever, it would actually feel like I'm 
degraded as a Coloured person because why are you trying to speak like that [...] it makes me feel mocked in a sense because of the way I speak (Interviewee 2).

The two figures below display the most recurring terms our interviewees used to describe both varieties of Afrikaans. It is easy to determine that the words describing the White variety carry a more positive meaning than the ones chosen to describe the variety spoken by the Coloureds. This is an indication of the prestige that this variety still has in South Africa.

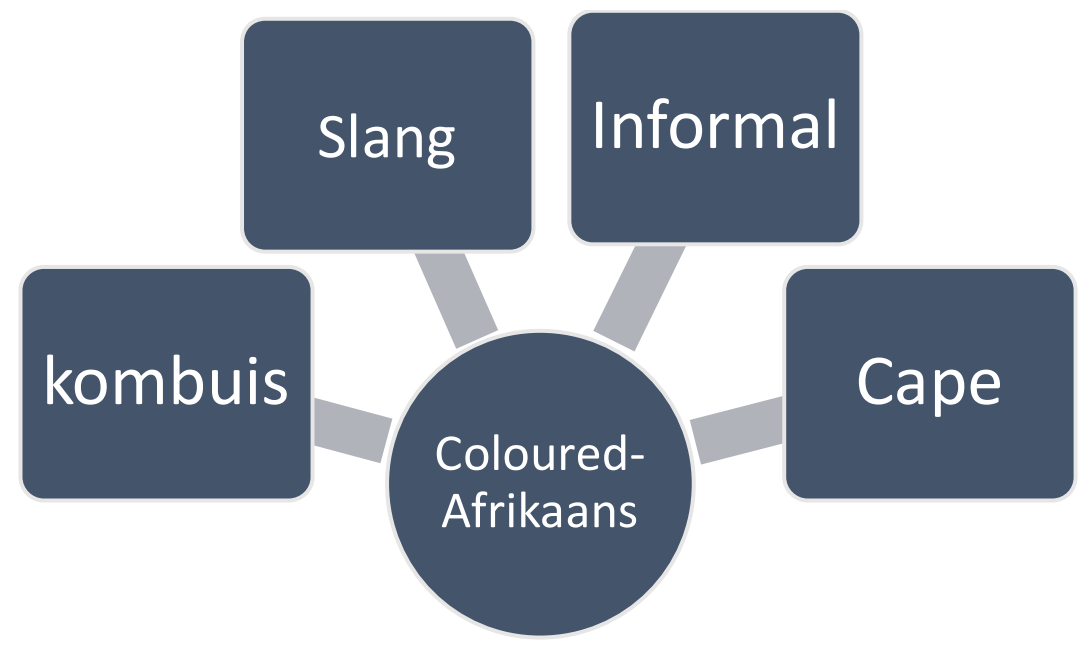

Figure 3 - Ascriptions used for Coloured-Afrikaans variety Source: Own Elaboration

Dyers (2008) carried out a sociolinguistic research in Wesbank (a neighbourhood of Cape Town) on language maintenance of Afrikaans and code-switching between English and Afrikaans. She argues that the dominant role of English in South Africa is misleadingly covered by some scholars and adds that "this large-scale shift, however, may either not be taking place or be taking place at a much slower rate in many communities of practice in South Africa" (DYERS, 2008, p. 49). According to her study, middle-class and upwardly mobile "mixed-race" individuals in South Africa are more 


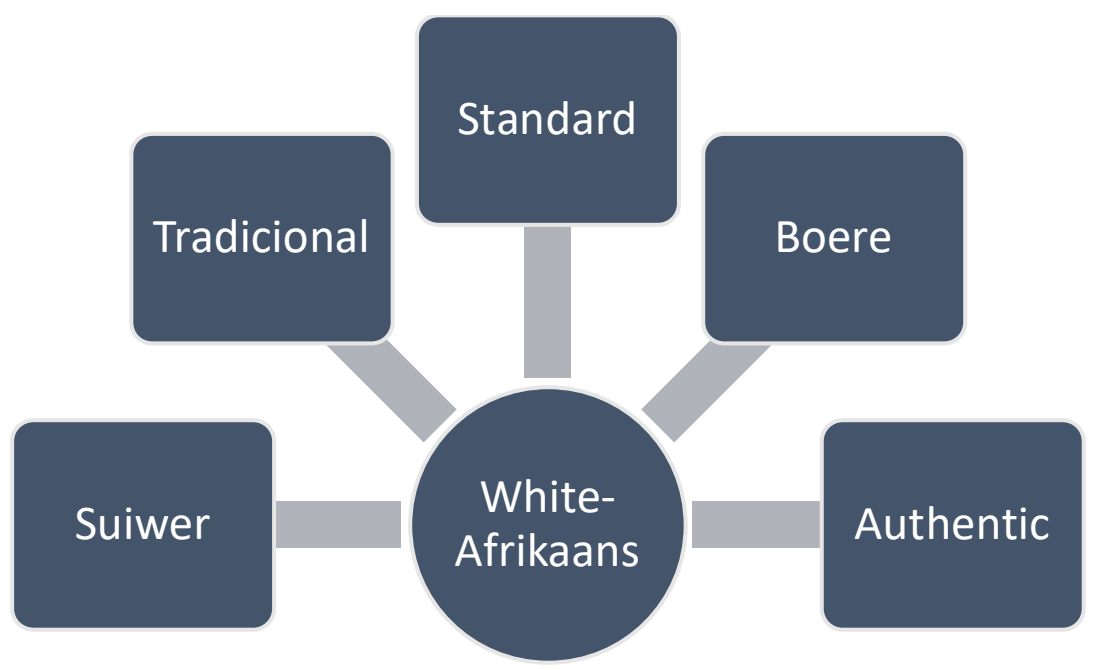

Figure 4 - Ascriptions used for White-Afrikaans variety Source: Own Elaboration

likely to present more use of English (and mixing languages) than poorer and rural communities. She supports the idea that, in these unprivileged locations, the broken educational system and historical levels of (il)literacy are some of the factors that contribute to the maintenance of home languages.

Concerning English, it seems like most of the Coloureds see it "as the language of access to better schooling, work and wider horizons" (DYERS, 2008, p. 135). The parents encourage their children to learn English because they feel that the future can be more prosperous with it. Apparently, the Coloured students interviewed for this research have a very positive attitude towards English and they use it in several domains. Also, important to remind that Cape Town is an international touristy city and the use of English just eases and attracts more people.

What is just as important, however, is the attitudinal aspect of the linguistic preference of English: Associated with the Soweto riots, English stands for the anti-colonial movement, particularly in educational affairs. It is only recently, that Afrikaans can recuperate some status.

As we have seen, nowadays, Afrikaans is not only the language of the White population. It is also the L1 of a large 
part of the South African society, the Coloureds, while the Black population - besides their (national, regional, and local) African first languages - favours English. The Coloured population - as Non-Whites and Non-Blacks - has been exempt to some extent from the ethnic polarity of the South African society. Their skin puts them alongside the Blacks; their language, however, positions them on the side of the former white rulers.

We noticed some pressure on Coloureds exerted by Black people, which was perceived by the interviewees who related this to the fact that Coloureds use the language of the White speakers:

(9) there was this one occasion it was in my first year, I think, I was like, I was speaking Afrikaans to this one he spoke Zulu so I speak Afrikaans with him, like just in a talking way but he was super offended like why do I take pride in such language? I mean he said it was a slavery language [...] this guy is actually attacking me, I feel insulted for Afrikaans.

The Afrikaans language, though, is usually not the standard one of the White populations but a substandard variety with English and other interferences, perceived as slang.

This again refers to the "in-between" status, which arouses suspicion from both sides: speaking not white enough to belong to the White Afrikaans community, speaking too much white to belong to the Black community which prefers English (and other languages). This stigmatizes the Coloured community in terms of social (or ethnic) as well as of linguistic criteria. And this is, conversely, subject to social aspirations and demand for recognition as an ethnic group and an accepted language on an equal footing.

\section{Conclusions}

The Coloured speaker community of Afrikaans is in a somehow delicate position of "in-between", not white, not black, and therefore, without clear status. To a certain extent, the traditional "racial" bias makes them invisible. Linguistically, their home language represents the white apartheid power. The spoken variety of that language, however, the Afrikaaps variety, based on Afrikaans and mixed with English and other 
linguistic elements, was seen as "slang", as impure, uneducated, satisfying neither the White speakers' community of "proper Afrikaans" nor the Black English-speaking community of its opponents. As for late, a new movement of linguistic pride emerged as a representation of social aspiration, of cultural identity, demanding an ethnic status for the Coloureds. This is backed by recent urban (and young) movements of new ethnic amalgamations, which are linguistically represented by code-mixing communities of practice. Since "language creates people's identities" (TABOURET-KELLER, 1997, p. 324), language mixing constitutes "emerging new hybrid ethnic identities", if not even an "erosion of ethnic divisions" (SLABBERT; FINLAYSON, 2000, p. 132). The linguistic emancipation of the Coloureds is manifested, of course, in a demanding and somehow contradictory process of the country's ethnic reconstruction: doing justice to previously suppressed ethnic groups and their languages is an urgent need of post-apartheid language policy, on the one hand. Recovering the linguistic vitality of ethnic groups will deepen the ethnic division of the society, on the other. Ethnicity is a matter of negotiation, construction, and sociocultural vitality. If ethnic groups are vital forces, ethnic framing is a productive source of construction of social relations depending on interests and attitudes. The Afrikaans speaking Coloured community demands its rights. Its fate follows the long way to a united country of diverse ethnicities.

We realise in this paper that there are many different groups of Black like Xhosa, Zulu and others and two kinds of Whites: English and Boere. However we cannot state if the Coloureds's role will consist in ethnic balancing due to their ethnic hybridity, reinforcing social tensions due to their ethnic aspiration, or if they will lose their linguistic representation by adopting English (or - unlikely - "proper Afrikaans"). 


\section{REFERENCES}

ANDERSON, Benedict. Die Erfindung der Nation. Zur Karriere eines folgenreichen Konzepts. Frankfurt/Main, New York: Campus 1988.

BARTH, Fredik. Introduction. In: BARTH, Fredik. Ethnic Groups and Boundaries. The Social Organization of Culture Difference. Bergen, Oslo: Universitets Forlaget; London: Allen and Unwin, 1969. p. 9-38.

BARTH, Fredik. Enduring and emerging issues in the analysis of ethnicity. In: GOVERS, Cora; VERMEULEN, Hans (org.) The Anthropology of Ethnicity. Beyond "Ethnic Groups and Boundaries". Amsterdam: Het Spinhuis, 1994. p. 11-32.

BRUBAKER, Rogers. Ethnicity without Groups. London: Harvard University Press, 2002.

Deumert, Ana; Inder, Brett; Maitra, Pushkar. Language, Informal Networks and Social Protection. Global Social Policy vol. 5(3) pp. 303-328, 2005.

DOWLING, Tessa; MCCORMICK, Kay; DYERS, Charlyn. Language Contact in Cape Town In: English in Multilingual South Africa. Cambridge: Cambridge University Press, 2020.

DYERS, Charlyn. Language shift or maintenance? Factors determining the use of Afrikaans among some township youth in South Africa. Stellenbosch Papers in Linguistics, vol. 38, p. 49-72, 2008.

EBERHARD, David M.; SIMONS, Gary F.; FENNIG, Charles D. (eds.). Ethnologue: Languages of the World. $23^{\text {rd }}$ ed. Dallas, Texas: SIL International 2020. Available at: $<$ http://www.ethnologue. com>. Access in 30 Sept. 2020.

ESSER, Hartmut: Die Entstehung ethnischer Konflikte. In: Hradil, Stefan (Hrsg.): Diffe-renz und Integration. Die Zukunft moderner Gesellschaften. Frankfurt am Main: Campus 1997, p. 876-894.

LE PAGE, Robert B.; TABOURET-KELLER, Andrée. Acts of Identity. Creole-based approaches to language and ethnicity. Cambridge: Cambridge University Press, 1985 
MAYRING, Philipp. Qualitative content analysis: theoretical foundation, basic procedures and software solution. Klagenfurt, 2014. Available at: <http://nbn-resolving.de/urn:nbn:de:0168ssoar-395173>. Access in: 28 Sept. 2020.

MESTHRIE, Rajend. Language in South Africa. Cambridge: Cambridge Press, 2004.

Omoniyi, Tope; White, Goodith. The Sociolinguistics of identity. London: Continuun, 2006.

PFAFF-CZARNECKA, Joanna. From "Identity" to "Belonging" in Social Research: Plurality, Social Boundaries, and the Politics of the Self. In: ALBIEZ, Sara; CASTRO, Nelly; JÜSSEN, Lara; YOUKHANA, Eva (eds.). Ethnicity, Citizenship and Belonging: Practices, Theory and Spatial Dimensions. Ethnicidad, ciudadania y pertenencia: prácticas, teoría y dimensiones espaciales. Frankfurt/ Main, Madrid: Iberoamericana, Vervuert, p. 199-219, 2011.

SCHIFFAUER,Werner; JOERDEN, J C; KOCH, Jochen; RECKWITZ, Andreas; SCHOOR, Kerstin (unter Mitarbeit von Hannes Krämer). Grenzen in Europa. Frankfurt (Oder): Viadrina Center B/Orders in Motion, 2018.

SLABBERT, Sarah; FINLAYSON, Rosalie (2000). “I'm a cleva!": The Linguistic Makeup of Identity in a South African Urban Environment. International Journal of the Sociology of Language, Vol. 144, p. 119-135. 2000.

TABOURET-KELLER, Andreé. Language and Identity. In: COULMAS, Florian (org.). The Handbook of Sociolinguistics. Malden: Blackwell, 1997. p. 315-326.

WEBB, Vic. Constructing an inclusive speech community from two mutually excluding ones: the third Afrikaans language movement. Tydskrif vir letterkunde, vol. 47, p. 106- 120. 2010.

WEBB, Vic; KRIEL, Marianna. Afrikaans and Afrikaner nationalism. International Journal of the sociology of language. Vol. 144, p. 19-49. 2000. 


\section{Resumo}

\section{Etnicidade linguística e cultural entre estudantes coloureds na Cidade do Cabo}

Este artigo levanta a questão da relação entre lingua eidentidade. Tema recorrente, nas últimas décadas, nos estudos de Sociolinguística e de outras ciências sociais, tais como Antropologia e Sociologia. O foco é descrever e apresentar a relação entre a língua afrikaans falada por estudantes universitários membros da etnia Coloured e a sua identidade linguística e étnica. O locus é a multicultural e plurilíngue Cidade do Cabo, situada na província do Cabo Ocidental sul africano, onde a colonização europeia começou. Para alcançar o objetivo deste artigo, apresentamos brevemente a lingua em questão: seu surgimento, sua história e por quem é falada atualmente. Além disso, por tratarmos de uma determinada etnia, usamos também suporte teórico antropológico da etnicidade. No que diz respeito à coleta de dados, usamos abordagem qualitativa. Foram realizadas entrevistas via internet através da plataforma conhecida como Zoom. Oito estudantes foram entrevistados e responderam a um conjunto de perguntas a respeito do papel social das variedades de afrikaans na Cidade do Cabo, suas atitudes linguísticas, a lingua que melhor os representa, entre outros assuntos. Os resultados obtidos com a investigação trouxeram um amplo entendimento das práticas linguísticas desses falantes coloureds.

\section{Palavras-chaves: Identidade.}

Pertencimento. Etnicidade. Afrikaans. 
Anderson Lucas da Silva Macedo é mestre em Estudos de Linguagem e doutorando em no mesmo Programa pela Universidade Federal Fluminense (PosLing-UFF). Desenvolve pesquisa com bolsa do Conselho Nacional de Pesquisa (CNPq).

Mônica Maria Guimarães Savedra é Doutora em Linguística pela UFRJ. Realizou pós-doutorado na Universität DuisburgEssen, Alemanha. Desenvolve pesquisas e orienta na área de Sociolinguística de Contato. Coordena o Laboratório de Pesquisa em Contato Linguístico da UFF (LABPEC) e o projeto "Multilinguismo, direitos linguísticos e desigualdade social" (CAPES-PrInt-UFF). Também é pesquisadora do CNPq e Cientista do Nosso Estado da FAPERJ.

Peter Rosenberg é Doutor em Germanística e em Geografia pela Freie Universität Berlin (FU). É docente e pesquisador na Fakultät für Kulturwissenschaften (Senior Lecturer) da Europa-Universität Viadrina, Frankfurt (Oder). Também é professor visitante no Projeto "Multilinguismo, direitos linguísticos e desigualdade social" (CAPES-PrInt-UFF) e no Programa Herder do DAAD (Serviço Acadêmico Alemão de Intercâmbio). 